\title{
Analisis Economic Value Added (EVA) dan Market Value Added (MVA) sebagai Alat Pengukur Kinerja Keuangan PT SA
}

\author{
Wilmar Amonio Gulo \\ Alumni Departemen Manajemen Fakultas Ekonomi dan Manajemen \\ Institut Pertanian Bogor \\ Wita Juwita Ermawati \\ Departemen Manajemen Fakultas Ekonomi dan Manajemen \\ Institut Pertanian Bogor
}

\begin{abstract}
The company should demonstrate good financial performance to attract investors by financial performance based on value-added and market value. The objectives of this study at PT SA limited were: (1) To analyze the financial performance by Economic Value Added (EVA) method, (2) To analyze the financial performance by Market Value Added (MVA) method. The results showed the company was not able to add economic value to the company, which proved by EVA in 2008 was higher than in 2009 . It is concluded that the company can not afford to pay obligations to investors as expected. However, different result showed by MVA, which indicates the company succes to managed the investor confidence over a given capital by increasing the value of capital invested. MVA showed results in 2008, the value of MVA was positive, and in 2009, the company's MVA achieved a significant increase in the amount of $379.42 \%$ from the previous year. The share price continued to increase making the MVA values continue to rise.
\end{abstract}

Key words: Economic Value Added, Market Value Added, financial performance

\section{Pendahuluan}

PT SA merupakan perusahaan terbuka yang bergerak di bidang perkebunan dan pengolahan kelapa sawit, dan telah melakukan penjualan saham kepada masyarakat (investor). Hal ini bertujuan untuk menambah modal kerja perusahaan, perluasan usaha dan diversifikasi produk. Untuk menarik investor, perusahaan harus mampu menunjukkan kinerja keuangan yang baik. Karena investor hanya akan berinvestasi atau membeli saham pada perusahaan dengan kinerja keuangan yang baik. Investor terlebih dahulu melakukan analisis dan mempertimbangkan apakah kinerja keuangan perusahaan tertentu baik atau tidak, sehingga modal yang diinvestasikan cukup aman dan mendapatkan tingkat pengembalian (rate of return) yang menguntungkan.

Metode yang telah banyak digunakan untuk menilai kinerja keuangan perusahaan adalah dengan menggunakan rasio keuangan. Perhitungan rasio keuangan ini dapat dengan mudah dilakukan, namun kelemahan metode ini adalah tidak dapat mengukur kinerja perusahaan dari sisi nilai perusahaan. Rasio keuangan hanya mengukur tingkat 
profitabilitas, likuiditas dan solvabilitas perusahaan (Sugiono, 2009). Konsep Economic Value Added atau EVA dapat melengkapi analisis rasio keuangan karena dapat mengukur kinerja secara tepat dengan memperhatikan sepenuhnya kepentingan dan harapan penyedia dana (kreditur dan pemegang saham). Dengan konsep ini dapat diketahui berapa sebenarnya biaya yang harus dikeluarkan sehubungan dengan penggunaan modal usaha perusahaan.

Penerapan konsep EVA dalam suatu perusahaan akan membuat perusahan lebih memfokuskan perhatian pada penciptaan nilai perusahaan. Hal ini merupakan keunggulan EVA dibandingkan dengan metode perhitungan yang lain. Selain itu keunggulan EVA yang lain adalah EVA dapat dipergunakan tanpa memerlukan data pembanding sebagaimana halnya rasio keuangan. Penggunaan EVA dapat dijadikan acuan mengingat EVA memberikan informasi dalam hal biaya modal sebagai kompensasi atas dana yang digunakan untuk membiayai investasi tersebut.

Selain konsep EVA, penilaian kinerja perusahaan juga dapat dilakukan dengan konsep MVA. Menurut Sartono (2001), tujuan utama perusahaan adalah memaksimalkan kemakmuran pemegang saham. Selain memberi manfaat bagi pemegang saham, tujuan ini juga menjamin sumber daya perusahaan yang langka dialokasikan secara efisien dan memberi manfaat ekonomi. Kemakmuran pemegang saham dimaksimalkan dengan memaksimalkan kenaikan nilai pasar dari modal perusahaan di atas nilai modal yang disetor pemegang saham. Kenaikan ini disebut Market Value Added (MVA). MVA merupakan hasil kumulatif dari kinerja perusahaan yang dihasilkan oleh berbagai investasi yang telah dilakukan maupun yang akan dilakukan. Dengan demikian, peningkatan MVA merupakan keberhasilan perusahaan dalam memaksimalkan kekayaan pemegang saham dengan alokasi sumber-sumber yang tepat. Dengan demikian MVA merupakan ukuran kinerja eksternal perusahaan.

Berdasarkan latar belakang diatas, maka perumusan masalah adalah PT SA dalam menilai kinerja keuangannya belum menghitung nilai EVA dan MVA. Padahal dengan menghitung nilai EVA dan MVA, perusahaan dan investor dapat mengetahui kinerja perusahaan tidak hanya dari aspek profitabilitas, likuiditas dan solvabilitas perusahaan, tetapi juga dari aspek nilai perusahaan baik secara internal (EVA) maupun eksternal (MVA). Dengan mengetahui nilai EVA dan MVA diharapkan perusahaan dan investor dapat mengevaluasi kinerja perusahaan secara lebih baik. Oleh karena itu penelitian ini dilakukan untuk mengetahui bagaimana kinerja keuangan PT SA jika memperhatikan nilai tambah ekonomis dan nilai pasar perusahaan.

Berdasarkan perumusan masalah, maka tujuan penelitian adalah sebagai berikut :

1. Menganalisis kinerja keuangan PT SA dengan metode EVA.

2. Menganalisis kinerja keuangan PT SA dengan metode MVA.

\section{Metode Penelitian}

Perusahaan-perusahaan yang tercatat di Bursa Efek Indonesia (BEI), secara periodik wajib menyampaikan laporan keuangannya. Laporan keuangan tersebut dapat dijadikan acuan secara fundamental bagaimana kinerja perusahaan dan bagaimana perusahaan dapat menciptakan nilai bagi pemegang sahamnya. Perusahaan yang diteliti adalah perusahaan perkebunan kelapa sawit yang telah terdaftar sebagai emiten BEI yaitu PT SA. PT SA sebagai perusahaan yang sedang berkembang 
membutuhkan dana yang berasal dari modal sendiri (ekuitas) maupun hutang (kewajiban) dalam melaksanakan aktifitas operasionalnya dan membangun bisnisnya. Dana tersebut dapat berupa pendanaan dari dalam perusahaan (internal financing) dan dari luar perusahaan (external financing). Struktur pendanaan perusahaan dapat mempengaruhi risiko dari hasil yang akan diperoleh perusahaan serta nilai perusahaan tersebut. Oleh karena itu perusahaan perlu mengetahui struktur pendanaan yang optimal yang dapat membawa perusahaan untuk dapat terus berlangsung hidup dan mencapai tujuannya, yaitu memaksimalkan kesejahteraan para pemiliknya.

Untuk mendapatkan berbagai alternatif pendanaan tersebut, berbagai penilaian maupun analisis yang digunakan untuk mengetahui kinerja keuangan perusahaan sangat dibutuhkan. Dalam menarik investor, perusahaan harus mampu menunjukkan kinerja keuangannya. Sebelum investor melakukan investasi, maka investor terlebih dahulu melakukan analisis kinerja keuangan perusahaan sehingga dapat memperoleh gambaran mengenai keadaan perusahaan. Konsep yang dapat mengukur seberapa besar kesejahteraan maupun kekayaan yang berhasil diciptakan perusahaan adalah EVA. EVA menggambarkan kemampuan perusahaan untuk menciptakan nilai tambah ekonomis. Selain itu perlu diketahui juga bagaimana nilai perusahaan berdasarkan pasar. Market Value Added merupakan hasil kumulatif kinerja perusahaan yang dihasilkan oleh berbagai investasi yang telah dilakukan maupun yang akan dilakukan untuk kemakmuran pemegang saham, dengan memaksimalkan kenaikan nilai pasar dari modal perusahaan di atas nilai modal yang disetor pemegang saham. Secara ringkas, kerangka pemikiran yang mendasari penelitian ini dapat dilihat pada Gambar 1 berikut ini. 
Penelitian dilaksanakan dari bulan Juni hingga Agustus 2010 dengan menggunakan data-data yang diperoleh dari website instansi publik yaitu: Bursa Efek Indonesia, Pusat Referensi Pasar Modal Bursa Efek Indonesia (PRPM BEI), dan Bank Indonesia. Penelitian ini menggunakan data sekunder yang bersifat kualitatif maupun kuantitatif. Data sekunder yang digunakan antara lain: laporan keuangan PT SA yang tercatat di Bursa Efek Indonesia periode 2008-2009 beserta gambaran umum perusahaan, dividen dan harga saham perusahaan beserta tingkat suku bunga bulanan Sertifikat Bank Indonesia periode 2008-2009. Laporan keuangan yang digunakan adalah laporan laba rugi dan neraca tahunan perusahaan.

Pengumpulan data dilakukan dengan studi pustaka dan kajian literatur yang menunjang untuk digunakan dalam penelitian ini. Data-data tersebut diperoleh dari buku, jurnal, laporan penelitian dan media elektronik. Data dan informasi yang telah dikumpulkan, kemudian diolah untuk dianalisis secara kuantitatif. Hasil analisis kuantitatif ini kemudian diinterpretasikan secara deskriptif. Adapun analisis kinerja keuangan PT SA tersebut menggunakan metode EVA dan MVA.

Ada beberapa tahapan dalam menghitung EVA. EVA dihitung setelah semua komponen pembentuknya diketahui. Selanjutnya dimasukkan ke dalam rumus perhitungan EVA. Ringkasan perhitungan EVA dapat dilihat pada Tabel 1.

Tabel 1. Langkah-langkah Perhitungan EVA

\begin{tabular}{|c|c|}
\hline Tahapan & Perhitungan \\
\hline 1. NOPAT & NOPAT = Laba Bersih + Biaya Bunga \\
\hline \multirow[t]{3}{*}{ 2. $\left(K^{*}\right)$} & $\mathrm{Kd}=\underline{\text { Biaya bunga }}$ \\
\hline & hutang \\
\hline & $\mathrm{Kd}^{*}=\mathrm{Kd}(1-\mathrm{T})$ \\
\hline 1. (Ke) & $K e=R_{f}+\beta\left(R_{m}-R_{f}\right)$ \\
\hline \multirow[t]{4}{*}{ 2. Struktur Modal } & Wd $=\underline{\text { Hutang }}$ \\
\hline & Aset \\
\hline & We $=\underline{\text { Ekuitas }}$ \\
\hline & Aset \\
\hline 3. WACC & $W A C C=\left[\left(K^{*} W d\right)+(K e \times W e)\right]$ \\
\hline 4. IC & IC $=$ Asset - Non Interest Liabilities \\
\hline 5. $\mathrm{COC}$ & $C O C=W A C C \times I C$ \\
\hline 6. EVA & $E V A=N O P A T-C O C$ \\
\hline
\end{tabular}

Sumber: Utama, 1997

Adapun langkah-langkah dalam menghitung Biaya Ekuitas (Ke) menggunakan model CAPM sebagai berikut:

$$
\text { 1. } R_{i t}=\frac{P_{i t}-P_{i t-1}+D_{t}}{P_{i t-1}}
$$

Dimana $R_{i t} \quad=$ tingkat pengembalian saham perusahaan tahun ke-t

$\mathrm{P}_{\text {it }} \quad=$ harga saham per lembar tahun $\mathrm{t}$

$\mathrm{P}_{\mathrm{it}-\mathrm{I}} \quad$ = harga saham per lembar tahun sebelumnya

$D_{t} \quad=$ dividen pada tahun $t$

$$
\text { 2. } \begin{aligned}
& R_{m t}=\frac{I H S G}{I H S G}-I H S G_{t-1} \\
& E\left(R_{m}\right)=\sum R_{m t}
\end{aligned}
$$


$\mathrm{N}$

Di mana

$\mathrm{R}_{\mathrm{mt}} \quad=$ tingkat pengembalian pasar pada tahun ke-t

$\mathrm{N} \quad$ = jumlah data

$E\left(R_{m}\right) \quad=$ tingkat pengembalian pasar yang diharapkan

3. $\beta_{i} \quad=\sigma_{i m}$

Dimana

$\beta_{\mathrm{i}} \quad=$ Beta saham $\mathrm{i}$

$\sigma_{\mathrm{im}} \quad=$ kovarian tingkat pengembalian saham i dengan tingkat

pengembalian pasar

$\sigma_{m}^{2} \quad=$ varian tingkat pengembalian pasar

4. $\mathrm{R}_{\mathrm{f}} \quad=$ Tingkat pengembalian bebas risiko menggunakan tingkat suku bunga Sertifikat Bank Indonesia

5. Ke $=R_{f}+\beta_{i} E\left(R_{m}-R_{f}\right)$

Rumus yang digunakan adalah penjumlahan antara tingkat risiko yang didapat dari (SBI) dengan koefisien beta dari saham yang didapat dari pengembalian saham biasa relatif terhadap pasar secara keseluruhan dan beta tersebut dikalikan dengan premi risiko pasar (Keown, et al, 2004).

Menurut Young dan O'Byrne (2001), nilai MVA dapat dihitung dengan rumus : $\mathrm{MVA}=$ nilai pasar ekuitas - modal ekuitas yang diinvestasikan investor

Nilai pasar ekuitas merupakan perkalian antara harga pasar saham perusahaan dengan jumlah saham yang beredar (shares outstanding). Harga pasar yang digunakan adalah harga pasar tahunan yang didapat dari harga pasar saham yang tercantum pada akhir periode tahun tersebut. Sedangkan jumlah saham yang beredar merupakan jumlah saham perusahaan yang dipegang oleh investor selama periode tahunan.

\section{Hasil Penelitian}

Besarnya perbedaan antara harga rata-rata Crude Palm Oil (CPO) di tahun 2009 dibanding tahun 2008 membuat hampir tidak mungkin bagi PT SA untuk menjadikan pencapaian di tahun 2008 sebagai acuan kinerja operasional untuk tahun 2009. Total pendapatan konsolidasi dari penjualan kecambah (benih sawit), CPO dan produk lain di tahun 2009 mencapai Rp1.815,6 miliar, turun 21\% dari Rp2.288,1 miliar di tahun 2008. Penurunan tersebut terutama disebabkan oleh terjadinya penurunan secara signifikan pada harga jual rata-rata CPO karena melambatnya ekonomi global, dan juga karena menurunnya volume penjualan CPO. Pada tahun 2008 harga rata-rata CPO yang diperdagangkan di MDEX (Malaysian Derivatives Exchange/Bursa Derivatif Malaysia), menyentuh rekor tertinggi mencapai MYR 2.864 per ton (Ringgit Malaysia). Pada tahun 2009 harga rata-rata CPO mencapai MYR2.261 per ton (dalam Ringgit Malaysia). Produksi minyak sawit pada tahun 2009 sedikit menurun sebesar 0,5\% menjadi 264.162 ton dibandingkan 265.468 ton pada tahun 2008. Penjualan produk Perseroan mengalami penurunan sebesar 21\% dari Rp 2.288,1 miliar di tahun 2008 menjadi Rp1.815,6 miliar di tahun 2009. Ringkasan laporan laba rugi perseroan pada tahun 2008-2009 dapat dilihat pada Tabel 2 di bawah ini. 
Tabel 2. Ringkasan Laporan Laba Rugi Konsolidasi PT SA Tahun 2008-2009 (Dalam Ribuan Rupiah)

\begin{tabular}{lrr}
\hline \multicolumn{1}{c}{ Komponen } & \multicolumn{1}{c}{2008} & \multicolumn{1}{c}{1.815 .557 .167} \\
\hline Penjualan & 2.888 .143 .121 & 1.216 .130 .626 \\
Beban pokok penjualan & 1.512 .477 .229 & 99.426 .541 \\
Laba kotor & 775.665 .892 & 139.389 .407 \\
Beban usaha & 164.209 .981 & 460.037 .134 \\
Laba usaha & 611.455 .911 & $(50.678 .760)$ \\
Penghasilan (beban) lain-lain & 20.305 .894 & 409.358 .374 \\
Laba sebelum beban pajak penghasilan badan & 631.761 .805 & $(123.134 .555)$ \\
Jumlah beban pajak penghasilan badan & $(185.793 .379)$ & 286.223 .819 \\
Laba sebelum hak minoritas atas laba bersih & 445.968 .426 & \\
anak perusahaan & & 281.766 .208 \\
Laba bersih & 439.516 .256 & 151 \\
Laba bersih per saham dasar & 236 &
\end{tabular}

Laba perseroan di tahun 2009 juga lebih rendah daripada tahun 2008, terutama disebabkan oleh menurunnya pendapatan konsolidasi yang menyebabkan penurunan marjin. PT SA mendapatkan laba bersih sebesar Rp 281,8 miliar di tahun 2009, sedangkan di tahun 2008 sebesar Rp 439,5 miliar. Hal ini mencerminkan laba per saham sebesar Rp 151 di tahun 2009 sedangkan di tahun 2008 sebesar Rp 236. Laba bersih terhadap jumlah aset mencapai 12,5\% di tahun 2009, sedangkan di tahun 2008 sebesar 20,4\%. Pada tahun 2009, laba bersih terhadap jumlah ekuitas mencapai 16,0\%. Adapun di tahun 2008 sebesar 28,3\%. Ringkasan neraca konsolidasi PT SA tahun 20082009 dapat dilihat pada Tabel 3 di bawah ini.

Tabel 3. Ringkasan Neraca Konsolidasi PT SA Tahun 2008-2009 (Dalam Ribuan Rupiah)

\begin{tabular}{lrr}
\hline \multicolumn{1}{c}{ Komponen } & \multicolumn{1}{c}{2008} & \multicolumn{1}{c}{2009} \\
\hline Aset lancar & 803.628 .697 & 615.541 .739 \\
Aset tidak lancar & 1.352 .535 .319 & 1.646 .256 .500 \\
Jumlah Aset & 2.156 .164 .013 & 2.261 .798 .239 \\
Kewajiban lancar & 354.044 .207 & 235.648 .479 \\
Kewajiban tidak lancar & 223.944 .244 & 239.318 .606 \\
Jumlah kewajiban & 577.988 .451 & 474.967 .085 \\
Jumlah ekuitas bersih & 1.552 .963 .652 & 1.765 .580 .591 \\
Jumlah kewajiban dan ekuitas & 2.156 .164 .013 & 2.261 .798 .239 \\
\hline
\end{tabular}

Sumber : Laporan keuangan PT SA

(EVA) merupakan suatu metode pengukuran kinerja perusahaan yang menghitung laba ekonomis sebenarnya yang telah berhasil diciptakan oleh suatu perusahaan. Dengan menghitung nilai EVA, perusahaan dapat melihat suatu gambaran mengenai peningkatan atau penurunan nilai laba ekonomis yang sebenarnya tercipta dari kinerjanya, sehingga diketahui posisi perusahaan menurut sudut pandang investor, apakah perusahaan telah menjadi wealth creator atau wealth destroyer.

Nilai EVA PT. SA pada tahun 2008 lebih tinggi dibandingkan tahun 2009. Penurunan ini disebabkan oleh perubahan-perubahan nilai komponen-komponen EVA. Komponenkomponen EVA terdiri dari Net Operating After Tax (NOPAT) dan Cost of Capital (COC). Yang dimaksud dengan NOPAT yaitu laba operasi bersih sesudah pajak, sedangkan COC adalah semua biaya yang secara riil dikeluarkan oleh perusahaan dalam rangka 
mendapatkan sumber dana baik yang berasal dari hutang, saham preferen, saham biasa, maupun laba ditahan untuk membiayai investasi perusahaan. Nilai EVA pada tahun 2008 sebesar Rp 1.024.496.611.000 sedangkan pada tahun 2009 mengalami penurunan yang signifikan menjadi minus Rp 40.707.153.000. Ringkasan perhitungan nilai EVA yang telah dicapai perusahaan dapat dilihat pada Tabel 4.

Tabel 4. Ringkasan perhitungan nilai Economic Value Added (EVA) PT SA periode 2008-2009 (dalam ribuan rupiah)

\begin{tabular}{cccccc}
\hline Periode & $\begin{array}{c}\text { Laba bersih } \\
(\mathrm{Rp})\end{array}$ & $\begin{array}{c}\text { Biaya bunga } \\
(\mathrm{Rp})\end{array}$ & NOPAT (Rp) & COC (Rp) & EVA (Rp) \\
\hline 2008 & 439.516 .256 & 24.465 .833 & 463.983 .089 & -560.154 .522 & 1.024 .496 .611 \\
2009 & 281.766 .208 & 27.899 .266 & 309.665 .434 & $350.372 .587,02$ & -40.707 .153 \\
Selisih & 157.750 .048 & 3.433 .433 & 154.316 .655 & 910.887 .109 .41 & 1.065 .203 .764 \\
& $35,89 \%$ & $14 \%$ & $33 \%$ & $104 \%$ & $163 \%$ \\
\hline
\end{tabular}

Sumber: Laporan Keuangan dan Harga Saham PT SA (diolah)

Hasil perhitungan NOPAT pada tahun 2009 mengalami penurunan dibandingkan pada tahun 2008. Biaya bunga mengalami peningkatan tetapi tidak diimbangi dengan kenaikan laba bersih perusahaan. Biaya bunga tahun 2009 meningkat dari tahun sebelumnya sebesar Rp 3.433.433.000 sedangkan laba bersih mengalami penurunan sebesar Rp157.750.048.000. Oleh karena biaya bunga yang dibayarkan oleh perusahaan meningkat, maka berakibat pada penurunan nilai NOPAT.

Biaya hutang $\left(\mathrm{Kd}^{*}\right)$ perusahaan mengalami peningkatan dari 0,079 menjadi 0,082. Peningkatan ini disebabkan oleh kenaikan proporsi hutang dari Rp 217.000.000.000 menjadi Rp244.000.000.000. Biaya ekuitas (Ke) perusahaan juga meningkat dari minus 44,089\% menjadi 20,632\%. Pada tanggal 31 Desember 2009, jumlah ekuitas sebesar Rp1.766 miliar, mengalami kenaikan sebesar 14\% dibandingkan dengan ekuitas pada tanggal 31 Desember 2008 sebesar Rp1.553 miliar.

Berdasarkan data bulanan harga saham tahun 2008 dan 2009, PT SA memiliki koefisien beta yang positif yaitu 7,980 dan 3,260. Hal ini menunjukkan bahwa saham PT SA lebih agresif dari pasar. Pada suatu kesempatan harganya dapat naik sedemikian cepat melebihi kenaikan pasar atau Indeks Harga Saham Gabungan (IHSG). Namun pada saat pasar sedang turun, harganya akan turun lebih cepat dari pada pasar. Artinya, jika pasar sedang naik, saham tersebut akan mengalami kenaikan yang lebih tinggi daripada harga pasar (Sugiono, 2009).

Kondisi kenaikan biaya hutang dan biaya ekuitas perusahaan mengakibatkan biaya modal rata-rata tertimbang (WACC) mengalami peningkatan sebesar 47,954\% karena WACC diperoleh dari penjumlahan proporsi biaya hutang dengan proporsi biaya ekuitas. Nilai WACC pada tahun 2008 sebesar $-30,961 \%$ menjadi 16,994\% pada tahun 2009. Selain itu, kondisi ini juga dikarenakan proporsi ekuitas dalam struktur permodalan mengalami kenaikan dari 72,024\% tahun 2008 menjadi 78,061\% tahun 2009.

Nilai Invested Capital (IC) perusahaan mengalami peningkatan dari tahun yang sebelumnya sebesar Rp251.369.864.000. Pada tahun 2008, nilai IC perusahaan sebesar Rp1.810.415.739.000 dan pada tahun 2009 meningkat menjadi Rp2.061.785.603.000. Peningkatan ini disebabkan oleh penurunan jumlah hutang beban dan peningkatan 
jumlah aset perusahaan. Hutang beban yang merupakan bagian dari non interest bearing liabilities sebagai pengurang total aset perusahaan untuk mendapatkan nilai IC. Nilai hutang beban pada tahun 2008 lebih besar daripada tahun 2009.

Nilai rata-rata COC pada tahun 2009 lebih besar daripada tahun sebelumnya. Nilai COC pada tahun 2009 sebesar Rp350.372.587.000, sedangkan pada tahun 2008 sebesar minus Rp560.154.522.000. Naiknya biaya modal perusahaan ini mengakibatkan nilai EVA pada tahun 2009 mengalami penurunan dibandingkan tahun sebelumnya. Nilai EVA tahun 2008 sebesar Rp 1.024.496.611.000, sedangkan pada tahun 2009 sebesar minus Rp40.707.153.000.

\section{IV.1. EVA sebagai Pengukur Kinerja Keuangan}

Nilai EVA pada tahun 2008 menghasilkan angka yang positif karena nilai NOPAT lebih besar daripada nilai biaya modal perusahaan. Hal ini menunjukkan bahwa perusahaan sudah dapat menambahkan nilai ekonomis ke dalam perusahaan atau dengan kata lain perusahaan mampu menghasilkan nilai tambah ekonomi melalui kegiatan-kegiatan operasionalnya sehingga mampu membayar seluruh kewajibannya kepada penyedia dana (investor) dan pemerintah (pajak) tetapi juga mampu menghasilkan laba yang lebih tinggi bagi perusahaan.

Pada tahun 2009, nilai EVA menghasilkan angka yang negatif, dimana terjadi penurunan sebesar Rp1.065.203.764.000. Hal ini menunjukkan bahwa tidak terjadi proses nilai tambah atau dengan kata lain perusahaan tidak mampu membayarkan kewajiban kepada para penyandang dana atau kreditur sebagaimana yang diharapkan. Penurunan nilai EVA ini antara lain disebabkan oleh:

1. Penjualan

Penurunan ini terutama disebabkan oleh penurunan pada volume penjualan produk kelapa sawit dan kecambah kelapa sawit, serta harga penjualan rata-rata produk kelapa sawit yang lebih rendah. Penjualan produk kelapa sawit menurun $19 \%$ menjadi Rp1.762 miliar di tahun 2009 dibandingkan Rp2.186 miliar pada tahun 2008 yang disebabkan oleh penurunan volume penjualan minyak sawit sebesar $8,3 \%$ menjadi 263.458 ton di tahun 2009 dibandingkan 287.152 ton pada tahun 2008 . Harga jual rata-rata minyak sawit juga menurun 9,2\% dibandingkan dengan tahun 2008. Penjualan kecambah kelapa sawit menurun $59 \%$ dari $\mathrm{Rp} 95,5$ miliar di tahun 2008 menjadi Rp 39,5 miliar di tahun 2009, terutama disebabkan oleh penurunan volume penjualan kecambah dari 18,4 juta di tahun 2008 menjadi 5,9 juta di tahun 2008, namun sebagian dikompensasi dengan peningkatan harga jual kecambah sebesar 29\%. Volume penjualan ini menurun seiring dengan menurunnya permintaan pasar atas kecambah. Beban pokok penjualan perseroan pada tahun 2009 terdiri dari beban pemeliharaan kebun, panen, pembelian buah plasma, alokasi beban tidak langsung, pengolahan, penyusutan dan amortisasi, dan pergerakan persediaan. Beban pokok penjualan menurun sebesar 20\% dari Rp 1.512 miliar di tahun 2008 menjadi Rp1,216 miliar di tahun 2009, sejalan dengan penurunan penjualan. Penjualan merupakan unsur dari NOPAT. Penurunan penjualan ini akan menurunkan NOPAT yang pada akhirnya mengurangi nilai EVA. 


\section{Ekuitas}

Ekuitas atau modal sendiri perusahaan merupakan komponen dari Invested Capital (IC) dalam menghitung biaya modal perusahaan. Ekuitas pada tahun 2009 mengalami peningkatan sebesar 13,69\%. Pada tahun 2008, ekuitas perusahaan sebesar Rp1.552.963.652.000, sedangkan pada tahun 2009 naik menjadi Rp1.765.580.591.000. Kenaikan ini disebabkan oleh penjualan modal saham yang dibeli kembali dari laba bersih di tahun 2009 dimana sebagian terkompensasi dengan adanya pembagian dividen dari saldo laba tahun 2008 sebesar Rp 170,1 miliar. Kenaikan ekuitas ini berakibat pada kenaikan proporsi struktur modal ekuitas perusahaan, sehingga biaya ekuitas perusahaan lebih besar daripada biaya hutang perusahaan. Hal tersebut mengakibatkan nilai WACC pun meningkat sehingga nilai EVA mengalami penurunan.

\section{IV.2. Market Value Added (MVA)}

Market Value Added (MVA) menunjukkan kinerja pasar dari suatu perusahaan. Metode pengukuran ini dapat menggambarkan seberapa besar kemampuan perusahaan atas modal yang dimiliki investor karena melibatkan harga saham sebagai komponen utamanya. Harga saham mencerminkan kekuatan interaksi antara pembeli dan penjual. Selain itu, munculnya informasi baru mengenai perusahaan akan membuat permintaan dan penawaran berubah sehingga menghasilkan nilai pasar yang berubah juga. Informasi tersebut salah satunya adalah mengenai kinerja yang berkaitan dengan perusahaan. Pengaruh kinerja ini terkait dengan kegiatan atau aktivitas perusahaan dalam menghasilkan keuntungan atau laba. Semakin tinggi laba, harga saham pun akan bereaksi positif. Semakin positif nilai MVA, menunjukkan bahwa perusahaan memiliki kinerja yang baik, karena telah berhasil melakukan penambahan nilai atas modal yang dipercayakan investor kepada perusahaan (wealth creator). Ringkasan perhitungan nilai MVA yang telah dicapai perusahaan dapat dilihat pada Tabel 5.

Tabel 5. Ringkasan perhitungan nilai Market Value Added (MVA) PT SA periode 2008-2009 (dalam ribuan rupiah)

\begin{tabular}{|c|c|c|c|c|c|}
\hline Periode & $\begin{array}{c}\text { Harga saham } \\
\text { per lembar } \\
\text { (Rp/lembar) }\end{array}$ & $\begin{array}{l}\text { Jumlah } \\
\text { saham } \\
\text { beredar } \\
\text { (lembar) }\end{array}$ & $\begin{array}{l}\text { Nilai pasar } \\
\text { ekuitas } \\
\text { (Rp) }\end{array}$ & Ekuitas (Rp) & MVA (Rp) \\
\hline 2008 & 1.19 & 1.890 .000 & 2.249 .100 .000 & 1.552 .963 .652 & 696.136 .348 \\
\hline 2009 & 2.700 & 1.890 .000 & 5.103 .000 .000 & 1.765 .580 .591 & 3.337 .419 .409 \\
\hline \multirow[t]{2}{*}{ Selisih } & 1.51 & - & 2.853 .900 .000 & 212.616.939 & 2.641 .283 .061 \\
\hline & $127 \%$ & & $127 \%$ & $13,69 \%$ & $379,42 \%$ \\
\hline
\end{tabular}

Pada tahun 2008, nilai MVA yang dihasilkan positif. Hal ini menandakan perusahaan telah berhasil memelihara kepercayaan investor atas modal yang diberikan dengan meningkatkan nilai modal yang ditanamkan kepada investornya. Memasuki tahun 2009, nilai MVA yang dicapai perusahaan meningkat signifikan. MVA PT SA mengalami peningkatan sebesar $379,42 \%$ dari tahun sebelumnya. Harga saham yang terus mengalami peningkatan membuat nilai MVA terus meningkat. Walaupun pada tahun 
2009 nilai ekuitasnya meningkat sebesar Rp 212.616.939.000 dibandingkan tahun 2008, namun peningkatan nilai pasar ekuitas masih lebih besar dari ekuitasnya sehingga nilai MVA positif. Sementara itu, peningkatan harga saham dari tahun 2008 hingga tahun 2009 sebesar Rp 1.510 mengindikasikan bahwa terjadi peningkatan aktivitas interaksi antara permintaan dan penawaran saham PT SA sehingga membentuk harga ekuilibrium baru yang lebih tinggi.

\section{IV.3. MVA sebagai Pengukur Kinerja Keuangan}

Menurut Steward dalam Ruky (1999), dengan meningkatnya EVA dari tahun ke tahun, berarti suatu perusahaan telah meningkatkan MVA dan sebaliknya. Jika sebuah perusahaan memiliki nilai-nilai EVA yang negatif, maka nilai MVA kemungkinan juga akan negatif. Jika terdapat nilai-nilai EVA yang positif, maka nilai MVA positif. Oleh karena itu Steward berkeyakinan bahwa EVA adalah kunci untuk menciptakan nilai perusahaan dan memaksimalkan MVA.

Namun ketika harga saham yang merupakan unsur utama dari perhitungan MVA lebih bergantung kepada ekspektasi kinerja di masa yang akan datang daripada kinerja historis, maka sebuah perusahaan dengan nilai EVA yang negatif dapat saja memiliki nilai MVA yang positif asalkan para investornya mengharapkan dan berkeyakinan terjadinya perubahan kinerja keuangan yang lebih baik di masa yang akan datang. Hal ini dapat dipengaruhi oleh informasi yang diperoleh investor dan pencitraan perusahaan. Ada perusahaan yang sahamnya banyak dicari investor sehingga harga saham naik meskipun perusahaan tersebut memiliki EVA yang tidak baik. Sugiarsono (2002) menyatakan bahwa harga saham bersifat forward looking yang artinya harga saham mencerminkan harapan investor terhadap kemampuan perusahaan menghasilkan arus kas sekarang dan dimasa datang. Adapun EVA lebih bersifat backward looking, yakni melihat hasil yang telah dilakukan manajemen dalam satu periode sehingga tidak mengherankan bila saham dari beberapa perusahaan yang memiliki nilai EVA kurang baik tetap memiliki harga saham tinggi karena dicari banyak investor. Berhasil atau tidaknya perusahaan meningkatkan nilai MVA tergantung pada tingkat pengembaliannya. Semakin besar MVA, menunjukkan indikasi MVA semakin baik. Dari paparan tersebut dapat dikatakan bahwa nilai MVA positif menunjukkan perusahaan telah berhasil meningkatkan nilai modal yang telah diinvestasikan.

\section{Kesimpulan}

Berdasarkan analisis kinerja keuangan dengan menggunakan metode EVA, PT SA pada tahun 2008 memiliki nilai EVA yang positif sebesar Rp 1.024.496.61.000 yang berarti perusahaan telah mampu menciptakan nilai tambah ekonomi kepada investornya. Namun pada tahun 2009, perusahaan memiliki nilai EVA negatif sebesar minus Rp40.707.153.000 dan mengalami penurunan yang signifikan sebesar Rp 1.065.203.764.000 dari tahun 2008. Hal ini menunjukkan bahwa tidak terjadi proses nilai tambah ekonomi kepada investor.

Nilai MVA yang dicapai PT SA pada tahun 2008 sebesar Rp696.136.348.000 sedangkan pada tahun 2009 sebesar Rp3.337.419.409.000. Keduanya bernilai positif yang membuktikan bahwa perusahaan telah berhasil menciptakan kekayaan kepada pemegang sahamnya. 


\section{Daftar Pustaka}

Brigham, E. F dan J. F. Houstoun. 2006. Manajemen Keuangan (Terjemahan). Erlangga, Jakarta.

Fardiansyah, T. 2003. Betulkah EVA Mengukur Penciptaan Nilai?. Dalam Swasembada.http://swa.co.id/swamajalah/sajian/details. php?cid=1\&id=1490.

Husnan, S dan E. Pudjiastuti. 2004. Dasar-dasar Manajemen Keuangan. Unit Penerbit dan Percetakan Akademi Manajemen Perusahaan YKPN, Yogyakarta.

Keown, J. et al. 2004. Manajemen Keuangan : Prinsip dan Aplikasi Jilid I. PT Indeks Kelompok Gramedia, Jakarta.

Poeradisastra, T. 2001. Menelanjangi Kinerja Manajemen. SWA 20/XVII/4-7, Jakarta.

Rodoni, A dan H. Ali. 2010. Manajemen Keuangan. Mitra Wacana Media, Jakarta.

Ruky, S M. 1999. Menilai Penyertaan dalam Perusahaan. Gramedia Pustaka Utama, Jakarta.

Sartono, A. 2001. Manajemen Keuangan Teori dan Aplikasi. BPPE, Yogyakarta.

Sugiono, A. 2009. Manajemen Keuangan untuk Praktisi Keuangan. Gramedia Widiasarana Indonesia, Jakarta.

Taufik. 2001. Penerapan EVA Mancanegara. Markplusnco http://www.markplusnco.com/ download/penerapan EVA mancanegara.pdf

Turangan, J.A. 2003. Economic Value Added dan Market Value Added: Model Peramalan Kesejahteraan Pemegang Saham. Jurnal Akuntansi Vol VIII.

Utama, S. 1997. Economic Value Added: Pengukuran Penciptaan Nilai Perusahaan. Majalah Usahawan No. 04 TH XXVI April 1997. Hal 10-13.

Young, S. D and S. E. O'byrne. 2001. EVA dan Manajemen Berdasarkan Nilai: Panduan Praktis untuk Implementasi. Salemba Empat, Jakarta. 